\title{
A New Approach on the Amino Acid Lysine Quantification by UV-Visible Spectrophotometry
}

\author{
HABIB BOUZID ${ }^{1,2,3}$, CESAR M. C. FILHO², JOANA RITA C. MARQUES ${ }^{1}$, \\ ARTUR J. M. VALENTE ${ }^{2}$, LICINIO M. GANDO-FERREIRA ${ }^{1 *}$ \\ ${ }^{1}$ University of Coimbra, CIEPQPF, Department of Chemical Engineering, Rua Silvio Lima - Pólo II, Pinhal de Marrocos, \\ 3030-790 Coimbra, Portugal \\ ${ }^{2}$ University of Coimbra, CQC, Department of Chemistry, Rua Larga, 3004-535Coimbra, Portugal \\ ${ }^{3}$ Department of Process Engineering, University of Mostaganem, BP. 227 Route de Bel-Hacel, 27000 Mostaganem, Algeria
}

\begin{abstract}
The methodology of the amino acid lysine (Lys) analysis using ninhydrin (Nin) reagent by spectrophotometric method was in-depth studied and improved. The optimization of time, Lys to Nin volume ratio and temperature were explicitly investigated. A specific wavelength of $479 \mathrm{~nm}$ was set according to the peak of the absorbance spectrum. The reaction time between Lys and Nin, in aqueous solution, occurs during $50 \mathrm{~min}$. The Lys/Nin ratio 1.67 appeared most effective for this reaction. Moreover, the absorbance increased with temperature until a stable value was achieved nearly at $85^{\circ} \mathrm{C}$. It was also found that the reaction is more efficient at initial $\mathrm{pH} 6$ corresponding to formation of high amount of coloured product. Furthermore, the $\mathrm{pH}$ of post-reaction mixture was around 4 for different concentrations of lysine and initial pH range 3-10. For lysine solution contaminated with potassium (a representative interfering species) and after variation of the reaction conditions, the maximum wavelength $(479 \mathrm{~nm})$ was not affected. Mastering the use of these parameters leads to a good usage of this analytical technique which is simple, fast, accurate, less expensive and especially less harmful towards the environment and human health.
\end{abstract}

Keywords: amino acid lysine, ninhydrin reagent, $U V$-Visible spectrophotometric analysis, optimization

\section{Introduction}

There is a growing demand for amino acids as value-added substances since they have many potential applications in the food, clinical, pharmaceutical and cosmetic industries, among others [1-7]. Amino acids have also an essential role in regulating neural activities in vivo [7] and have a great importance in all basic biological processes in the cell [8]. They are also used in the synthesis of certain biomaterials such as silk fibroin-magnetite for wounds healing [9].

Most L-amino acids are currently produced by fermentation processes leading to desired amino acids and inorganic species [10,11]. The implementation of simple and reliable techniques of amino acid analysis is an essential issue in the field of industrial biotechnology applied to production of added-value chemicals. Leca-Bouvier and Blum [12] reported that the colorimetric procedure is very successful when it relies on using representative calibration standards. High-performance liquid chromatography (HPLC) is the most popular method for quantifying amino acids but a derivatizing reagent, which selectively reacts with the amino group, should be used $[12,13]$. The reaction of ninhydrin (2,2-dihydroxy-1,3-indanedione) with a primary amino group to form a coloured compound has been extensively employed in quantitative and qualitative amino acid analysis. Taking into consideration the additional steps of the pretreatment of samples for the retention time of lysine, the analysis time considerably increases and the method becomes times-consuming when compared with the ninhydrin-based UV-vis spectrophotometric method. In addition, no expensive equipment is required for the latter methodology when compared to HPLC, which also needs a high qualified operator $[12,13]$.

*email: lferreira@eq.uc.pt 
The motivation behind the choice of lysine (Lys), is related not only with its importance in the global market of animal feed additives but also for its necessity to children's physical growth $[5,10,14,15]$. The current industrial process to purify Lys solutions is based on ion-exchange multicolumn systems that require an excessive consumption of water and ammonia, with a consequent generation of environmentally harmful effluents. Studies on alternative strategies based on clean technologies for separation/purification of Lys will lead to the fastest and easiest experimental methodology for analyzing this amino acid during the tests for assessment of the separation efficiency. Thus, we have improved and optimized an experimental method based on UV-visible spectrophotometric analysis for determination of Lys, by using ninhydrin.

There are a few methods in the literature that address the quantification of amino acids [16], including Lys [17], in the food products. The production of Lysine is based on a industrial fermentation process [18-21], which generates a culture broth formed by Lys and low concentration of contaminant species [21], being the ninhydrin colorimetric method the most used one to evaluated that reaction. Aiko et al. (1971) [22] found that salts, sugars, urea and ammonia, usually present in the culture broth, do not interfere with ninhydrin at the maximum absorbance wavelength found (475 $\mathrm{nm}$ ). Therefore, the interference of the above mentioned contaminant species will not occur in the present work since the maximum absorbance wavelength found $(479 \mathrm{~nm})$ is similar to that previously reported [22]. On the other hand, the interference of contaminant species can also be neglected since Lysine concentration is very high in the culture broth or in the original samples as reported by Bordons (1986) [18]. It is worth noticing that due to the absence of lysine manufacturing process in Portugal, no real samples were tested. However, a model solutionof lysine skipped with potassium, acting as a representative interfering inorganic specie was tested, by following the suggestion of Nagai and Carta (2004) [2, 21]. It should also be taken into account that the maximum absorbance wavelength depends on the solvent and added reactants in the reaction mixture [20].

At the best of our knowledge, the optimization of important variables, such as the added volume of lysine and ninhydrin reagent solutions or the time, temperature and $p \mathrm{H}$ of reaction, are not reported in the literature. For this reason, our main goal was to improve the method's reaction rate and go deeper on the optimization of parameters that might affect the quantitative analysis of Lys. Moreover, it is imperative to reduce the reaction time, around $2-3 \mathrm{~h}[23,24]$, and the temperature $\left(\mathrm{ca} .100^{\circ} \mathrm{C}\right)[13,18$, $19,23]$ of reaction between Lys and ninhydrin reagent, in order to become feasibly for practical terms.

The effect of $p \mathrm{H}$ on the color development in ninhydrin method was previously studied [13] for a variety of amino acid concentrations and in a restricted $p \mathrm{H}$ range (5.3-8.05), while in the present study was specifically analyzed for amino acid lysine and in a large $p \mathrm{H}$ range (2-11). Apart from this, the ratio of Lys to Nin was also investigated and identified as the most important parameter affecting the reaction. In this paper this method has been improved, by enhancing the reaction rate, and revisited from a different perspective to standardise the most varied reaction conditions. The optimization of reaction time, needed volumes of lysine and reagent solutions, reaction temperature, and $\mathrm{pH}$ was successfully achieved, leading to both better accuracy and lower cost, and contributing for a lower environmental impact as well.

\section{Materials and methods \\ Reagent and solutions}

Ninhydrin (2,2-dihydroxyindan-1,3-dione, 99\%) reagent was purchased from Sigma-Aldrich (Bucks, Switzerland), and its solution was daily prepared by dissolving $0.35 \mathrm{~g}$ of ninhydrin in $100 \mathrm{~mL}$ of ethanol [24-26]. Lysine (2,6-diaminohexanoic acid, 98\%), molar weight of $146.1876 \mathrm{~g} \mathrm{~mol}^{-1}$ and isoelectric point, pI, of 9.74 [27], was purchased from Sigma-Aldrich (Bucks, Switzerland). To study the interference of potassium, which is the representative contaminant species of lysine during its industrial fermentation process [21]. Thus, the Lysine- $\mathrm{KCl}$ solution was used in which it represents a lysine solution with $\mathrm{KCl} 10 \%$ solution. Adjustments of $\mathrm{pH}$ in the range 2-11 were carried out by using hydrochloric acid $\left(1 \mathrm{~mol} \mathrm{~L}^{-1}\right)$ and sodium hydroxide $\left(1 \mathrm{~mol} \mathrm{~L}^{-1}\right)$ under magnetic stirring. $\mathrm{HCl}(37$ 
wt.\%), potassium dihydrogen phosphate (99.5\%), potassium chloride (99\%), $\mathrm{NaOH}$ (pellets,98\%) and ethanol (99.8\%) were purchased from Ridel-de-Haën (Seelze, Germany). All solutions were freshly prepared using ultra-pure grade water, purified with a Milli-Q system from Millipore (Billerica, MA, USA).

\section{Instrumentation}

Absorbance spectra were recorded on UV-Visible UVWin5 Software V5.0.5 spectrophotometer T60 (UK), in the wavelength range $400 \mathrm{~nm}$ to $800 \mathrm{~nm}$ and a medium speed scan of $2 \mathrm{~nm} \mathrm{~s}^{-1}$.

The chromatography method for the separation and quantification of L-lysine was performed using a VWR-Hitachi LaChrom Elite HPLC system (Hitachi, Japan), equipped with a degasser, auto sampler, column oven, and DAD. For better separation of L-Lysine, an analytical column $(0.25 \mathrm{~m} \times$ $4.6 \mathrm{~mm}, 5 \mu \mathrm{m}$ film) Purospher ${ }^{\circledR}$ Star RP-18 endcapped (Merck-Millipore, Germany) was used. EZChrom Elite software (Agilent, USA) was used for data acquisition and processing.

\section{Experimental procedure}

At the first stage, $1 \mathrm{~mL}$ of ninhydrin solution was added to $5 \mathrm{~mL}$ of sample in a series of caped test tubes $[25,26]$ which were placed at $80{ }^{\circ} \mathrm{C}$ in the water-bath with a gentle stirring fixed at $70 \mathrm{rpm}$. This temperature was chosen in the interval between $80-100^{\circ} \mathrm{C}$ according to the previous studies with ninhydrin [13,18,19] and 2-hydroxynaphthaldehyde reagents [28]. After cooling the reaction tubes at room temperature, the solution absorbance corresponding to $1 \mathrm{~h}$ of reaction was measured by using a UV-Visible spectrophotometer. The maximum absorbance wavelength for of lysine and Lysine-KCl solutions, at different concentrations (0.1-0.9 mmol L-1), was recorded at ca. $479 \mathrm{~nm}$ (Figure 1). It is also worth noticing that the maximum absorbance wavelength does not depend on different experimental parameters as, for example, reaction time, ratio of lysine to ninhydrin, reaction temperature and $p \mathrm{H}$ (Figure S1). The optimization of experimental conditions was carried out by using a full-factorial design methodology. Hence, potassium, as a representative interfering species [2,21], did not interfere with ninhydrin at $479 \mathrm{~nm}$, in agreement with the work reported by Aiko et al. [22] and Bordons [18].
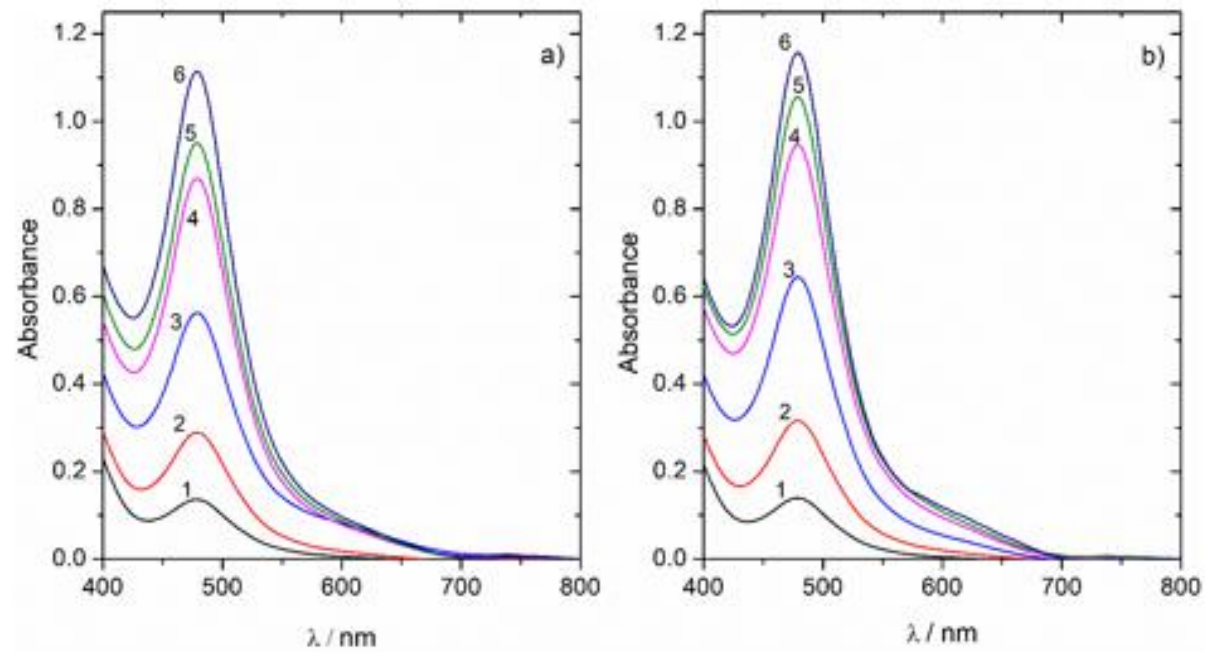

Figure 1. UV/vis absorbance spectra of a) aqueous lysine solutions and

b) Lysine-KCl solution after reaction with ninhydrin

$\left(0.35 \mathrm{~g} \mathrm{Nin} / 100 \mathrm{~mL}\right.$ ethanol) for 1 hour, at $80^{\circ} \mathrm{C}$. Lysine concentrations:

1) $0.1 \mathrm{mmol} \mathrm{L}-1,2) 0.2 \mathrm{mmol} \mathrm{L}^{-1}$, 3) $0.4 \mathrm{mmol} \mathrm{L}^{-1}$,

4) $0.6 \mathrm{mmol} \mathrm{L}-1$, 5) $0.8 \mathrm{mmol} \mathrm{L}^{-1}$, 6) $0.9 \mathrm{mmol} \mathrm{L}^{-1}$ 
The analytical methodology for quantification of lysine by HPLC was based on the method reported elsewhere [29]. In summary the mobile phase containing $10 \mathrm{mmol} \mathrm{L}^{-1}$ of potassium dihydrogen phosphate and the $p \mathrm{H}$ was adjusted at 7.5 by using trimethylamine. The detection was carried at $195 \mathrm{~nm}$. The flow rate of the mobile phase was set to $0.5 \mathrm{~mL} \mathrm{~min}^{-1}$, while the temperature of column maintained at $25^{\circ} \mathrm{C}$. The injection volume was $20 \mu$ Land each test required $5 \mathrm{~min}$. All samples solutions, standards and mobile phase were filtered through membrane filter of $0.45 \mu \mathrm{m}$.

All the lysine solutions were prepared by placing appropriate amounts of L-lysine in a $100 \mathrm{~mL}$ volumetric flask containing ultrapure water. Lysine- $\mathrm{KCl}$ solutions were prepared using a stock solution of $40 \mathrm{mg} \mathrm{KCl} / 200 \mathrm{~mL}$ of ultrapure water (Table $\mathrm{S} 1$ in the supplementary material).

\section{Method validation \\ Linearity}

The standard calibration curves were obtained using aqueous solutions of lysine and Lysine- $\mathrm{KCl}$ solution in the concentration range $0.1-0.9 \mathrm{mmol} \mathrm{L}^{-1}$. Five replicate of each concentration were analyzed using the optimized parameters of ninhydrin method with UV-visible spectrophotometry. The linear regression equation and the corresponding determination coefficient $\left(R^{2}\right)$ were computed, as reported by ICH (International Conference on Harmonisation) [30], from a plot of absorbance versus lysine concentration and Lysine- $\mathrm{KCl}$ solution concentration.

\section{Precision}

The relative standard deviation (RSD) of the determinations was computed as follows [31-34]:

$$
(R S D \%)=\left(\frac{S D}{A b s_{m}}\right) \times 100
$$

where $S D$ is the standard deviation of the five/ten replicate, respectively, measured at two different days [day $1(\mathrm{n}=5)$, day $2(\mathrm{n}=10)$ ] [29,32], and $A b s_{\mathrm{m}}$ is the mean value of absorbance for the five/ten replicate of each concentration varying from 0.1 to $0.9 \mathrm{mmol} \mathrm{L}^{-1}$.

\section{Limits of quantification (LOQ) and of detection (LOD)}

The LOQ and LOD were calculated based on the standard deviation of the response at low concentrations $(S D)$ of the calibration curve and respective slope $(S)$ using the following equations $[30,32,35]$ :

$$
\begin{aligned}
& L O Q=10 \times\left(\frac{S D}{S}\right) \\
& L O D=3.3 \times\left(\frac{S D}{S}\right)
\end{aligned}
$$

\section{Accuracy}

The accuracy of the proposed method was evaluated by determining the recovery values for five replicate of each concentration, as reported by AOAC International [36], varying from 0.1 to $0.9 \mathrm{mmol}$ $\mathrm{L}^{-1}$. The average percent recovery was calculated through the equation below [30,32,33,36,37]:

$$
\text { Recovery }(\%)=\left(\frac{C_{o b s}}{C_{s p i}}\right) \times 100
$$

where $C_{\text {obs }}$ and $C_{\text {spi }}$ are the experimental and spiked concentrations, respectively.

\section{Results and discussions}

In this section, optimization studies aiming the optimal values of key variables that affect the reaction between lysine and ninhydrin solutions will be discussed. The general reaction is shown in Figure 2. 


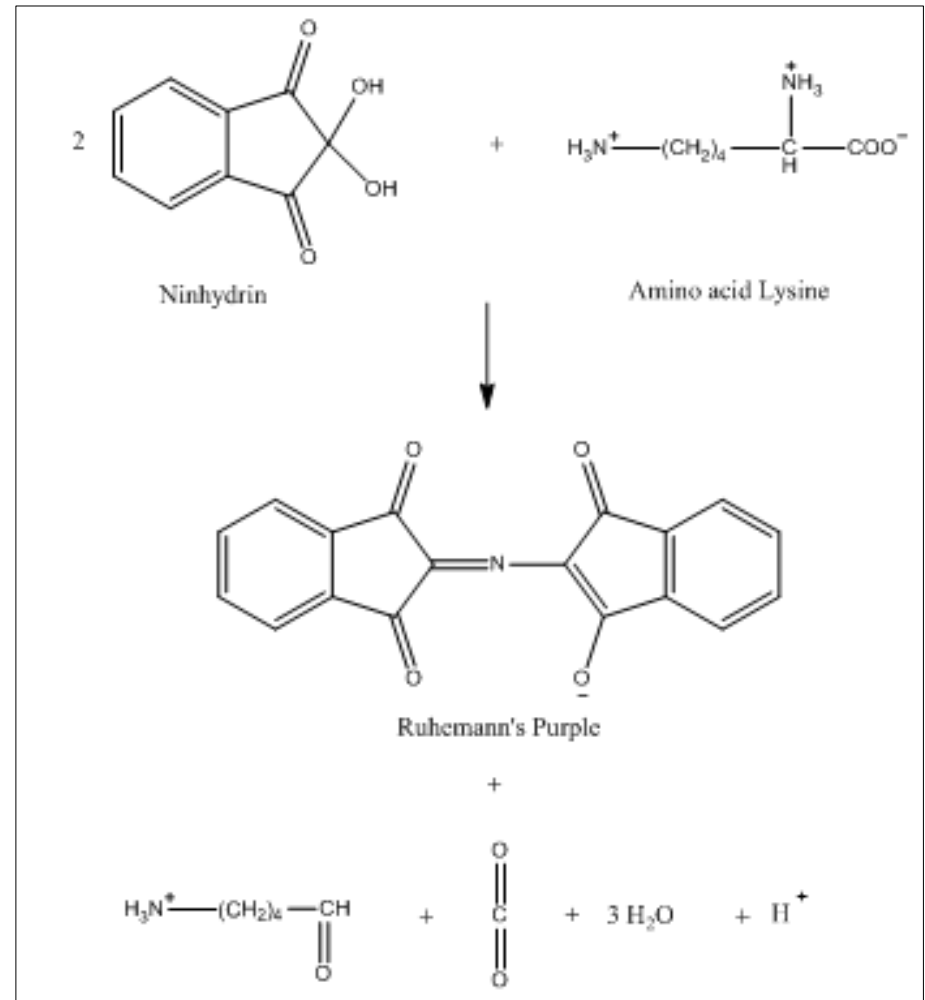

Figure 2. Chemical reaction of ninhydrin with amino acid Lysine in positively charged form (Lys ${ }^{+}$) to yield Ruhemann's Purple (adapted from Wigfield et al. (1980) [38]and Lehninger et al. (1993) [27])

\section{Effect of reaction time}

Figure 3 shows the dependence on the maximum absorbance of Lys/Nin solutions on the reaction time (from 5 to $70 \mathrm{~min}$ ).It can be seen that the absorbance increases by increasing the reaction time, reaching a maximum absorbance at approximately $50 \mathrm{~min}$. From the analysis of Figure 3, we can concluded that the rate constant is constant up to $50 \mathrm{~min}$ The establishment of the plateau revealed the existence of a limiting concentration for Ruhemann's Purple formation and can be explained by the cancellation of the reaction rate. These results indicate that the optimal reaction time is of 50 minutes and show that the required time for analyzing lysine with this methodology is lower than that the one needed to obtain the retention time of lysine peak by HPLC reported in previous works $[39,40]$. On the other hand, this reaction time $(50 \mathrm{~min})$ is feasible for practical terms when taking into consideration all additional steps of the experimental previously reported procedure $[13,18,24]$. In addition, a reduced consumption of ninhydrin quantity, corresponding to about one sixth [13] and one third [18], and reagents $[13,18]$, was noted.

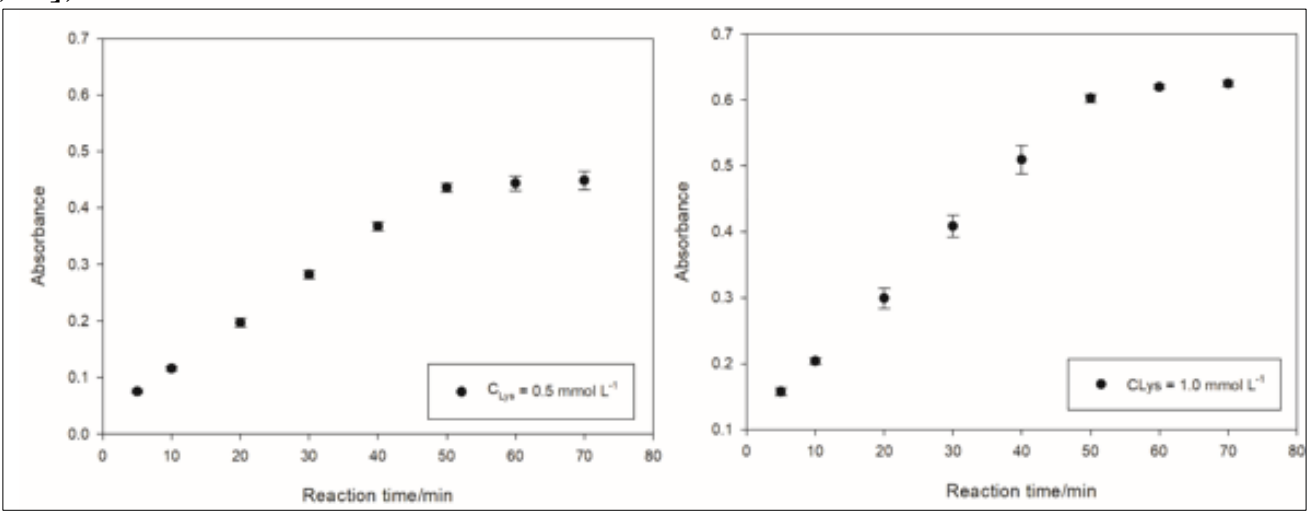

Figure 3. Dependence of the maximum absorbance at $479 \mathrm{~nm}$ on the lys-ninhydrin reaction time; a) $[\mathrm{Lys}]=0.5 \mathrm{mmol} \mathrm{L}{ }^{-1}$ and (b) $[\mathrm{Lys}]=1 \mathrm{mmol} \mathrm{L}^{-1}$, at $80^{\circ} \mathrm{C}$ and $[\mathrm{Lys} / \mathrm{Nin}]=5$ 


\section{Effect of volume of Lysine and reagent solutions}

The effect of volume of Lys, at two different concentrations $\left(0.5\right.$ and $\left.1 \mathrm{mmol} \mathrm{L}^{-1}\right)$, and ninhydrin (Nin) reagent solutions, at a fixed time $(50 \mathrm{~min})$, have been studied. By changing the volume of ninhydrin solution and kept the volume of Lys as equal to $2.5 \mathrm{~mL}$, we will be able to modify the volume Lys/Nin ratio from 0.33 to 10 . The obtained results are shown in Figures 4 and 5 . These figures show a similar trend for both Lys concentrations; i.e., the absorbance increases gradually until reaching a maximum at 0.592 and 1.184 , for Lysine concentrations of 0.5 and $1 \mathrm{mmol} \mathrm{L}^{-1}$ respectively. It can be concluded that the optimal volumes of Lys and ninhydrin reagent solutions are 2.5 and 1.5 $\mathrm{mL}$, respectively, corresponding to a volume ratio Lys/Nin of 1.67. At higher volume ratios, the reaction rate is not efficient and lead to low absorbance values. On the other hand, the excess of ninhydrin may lead to side reactions $[20,41]$.

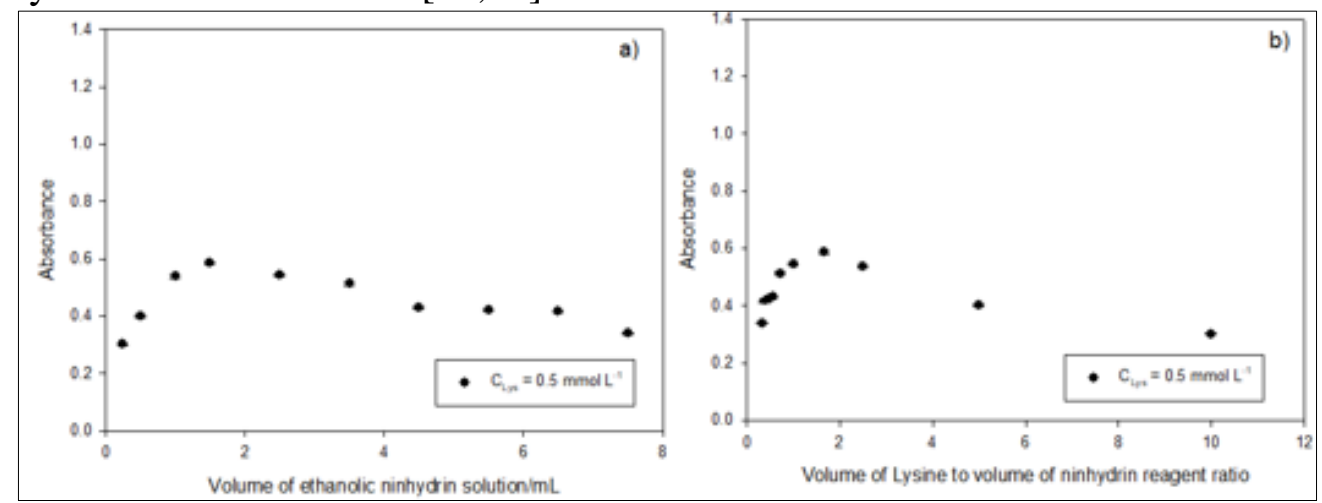

Figure 4. Variation of absorbance with volume of $0.5 \mathrm{mmol} \mathrm{L}^{-1}$ lysine (a) and Lys/Nin ratio (b) at $80^{\circ} \mathrm{C}$ for $50 \mathrm{~min}$

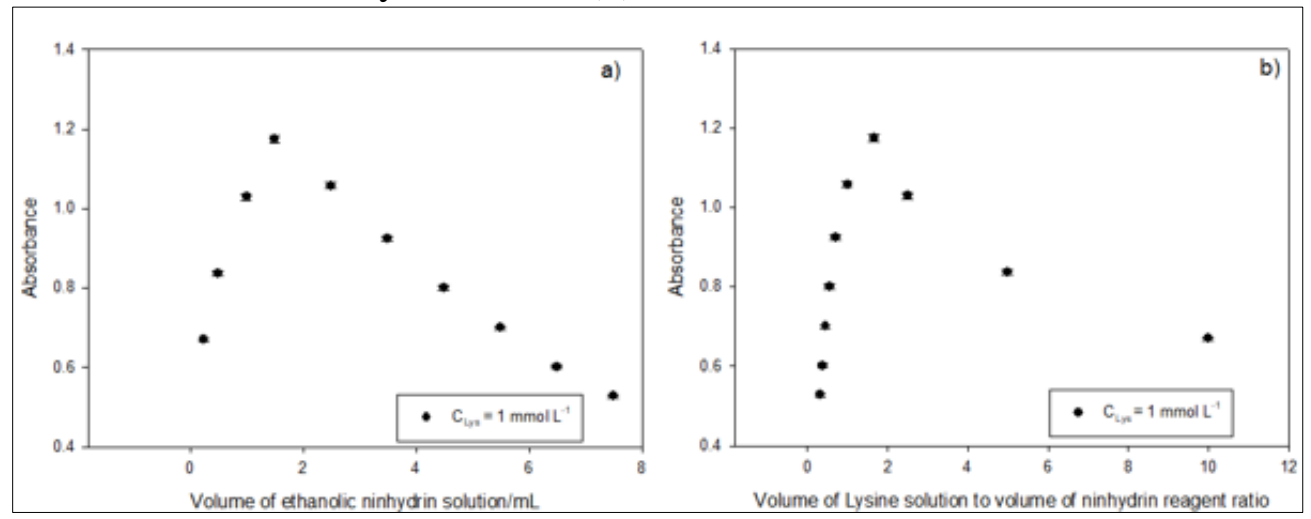

Figure 5. Variation of absorbance with volume of $1 \mathrm{mmol} \mathrm{L}^{-1}$ lysine

(a) and Lys/Nin ratio (b) at $80^{\circ} \mathrm{C}$ for $50 \mathrm{~min}$

\section{Effect of reaction temperature}

The reaction temperature was optimized by using 0.5 and $1 \mathrm{mmol} \mathrm{L} \mathrm{L}^{-1}$ Lysine solutions. The dependence of $A$ on the $T$ shows an interesting S-shape (Figure 6), reaching a plateau at $T$ around 80$85^{\circ} \mathrm{C}$. An insight on such behavior can arise from the kinetic mechanism analysis. At temperatures below $60-70^{\circ} \mathrm{C}$ the activation energy barrier to reach the transition state is not reached and, consequently, the absorbance due to Ruhemann's purple complex is low [42,43]. By increasing the $T$, a pre-steady-state kinetic [44] is reached and, consequently, the reaction rate increases leading to the formation Ruhemann's purple complex. At $80-85^{\circ} \mathrm{C}$ a decrease in the Ruhemann's purple complex formation is observed; this can be justified by a slowdown in the reaction rate followed by the addition of small activation energy thus slight increase in Gibbs free energy $(\Delta \mathrm{G})$ and in Ruhemann's purple complex productions. One hypothesis explaining the specific behavior is based on the fact that the enthalpy variation of the reaction to form the Ruhemann's purple complex is endothermic. This conclusion arises from the dependence of the reaction product concentration as a function of temperature. However, the decrease in the algebraic value of the Gibbs energy variation is only 
justified by a decrease in the entropy variation; i.e. $\Delta \mathrm{S}<\Delta \mathrm{H} / \mathrm{T}$ [45] which, in the limit, prevents the formation of the Ruhemann's purple complex. Above $85^{\circ} \mathrm{C}$ there was no further production of Ruhemann's purple complex once all the activated molecules of the reactants have already been forwarded to the transition state by forming a limiting concentration of the Ruhemann's purple complex.

The results obtained of the adopted methodology suggest that the optimum conditions are 50 min of reaction time (Figure 3), 1.67 as Lys/Nin ratio (Figures 4 and 5) and $85{ }^{\circ} \mathrm{C}$ of reaction temperature (Figure 6). It should be noted that the optimal reaction temperature is lower than those reported elsewhere $[13,18,19]$.

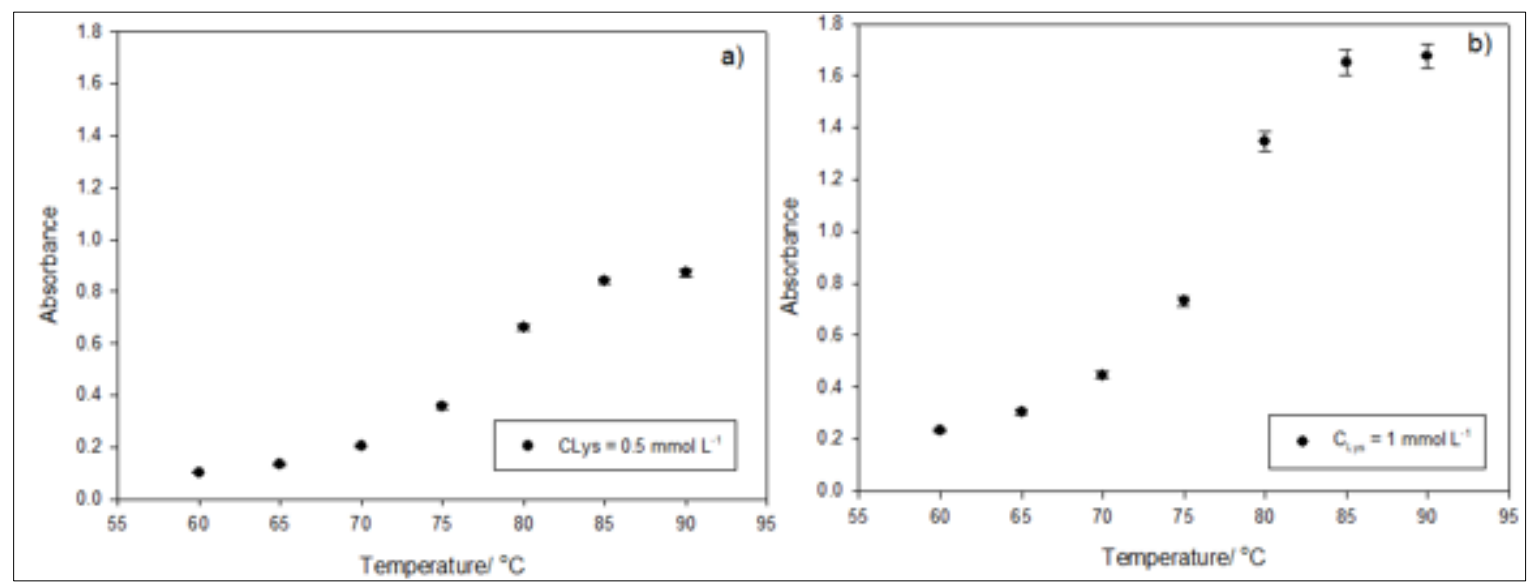

Figure 6. Variation of absorbance with reaction temperature for lysine concentrations of $0.5 \mathrm{mmol} \mathrm{L}^{-1}$ (a) and $1 \mathrm{mmol} \mathrm{L}^{-1}$ (b) with Lys/Nin ratio of 1.67 for $50 \mathrm{~min}$

\section{Effect of initial pH}

It is well known that the amount of colored product formed in the reaction between the amino acid and ninhydrin reagent is dependent on the $p \mathrm{H}$ at which the reaction is carried out. However, some chemical issues behind the reaction of the protonated or unprotonated form of the amino acid in solution with ninhydrin are still veiled. From the analysis of Figure 7, the effectiveness of the reaction increases by increasing the $p \mathrm{H}$ from 2 to 6 . So, it seems that the reaction is more efficient at initial $p \mathrm{H}$ 6 when the dominant form of the amino acid is positively charged $\left(\mathrm{Lys}^{+}\right)$according to the different forms of Lysine shown by Garrett and Grisham (2010) [46]. This optimum $p \mathrm{H}$ (6) found for lysine is near that one (5.5) reported by Friedman (2004) for all amino acids. It can be interestingly observed that $p \mathrm{H} 6$ is the mean of $\mathrm{pK}_{\mathrm{a}}$ of the carboxylic acid group $(-\mathrm{COOH})$, which is of 2.18, and $\mathrm{pI}(9.74)$ of Lysine. It can be concluded that when the $p \mathrm{H}$ is higher than $\mathrm{pK}_{\mathrm{a}}(-\mathrm{COOH})$ and lower than $\mathrm{pI}$ the lysine is in its most dissociated state notably at $\mathrm{pH} 6$ and, consequently, the chemical reaction (Figure 2) occurs with a significant rate. On the other hand, a zwitterionic form (Lys ${ }^{ \pm}$) predominates at pI value when the overall charge of the lysine molecule is cancelled causing a minimum solubility (and a lower reaction rate) of Lysine in solution. 


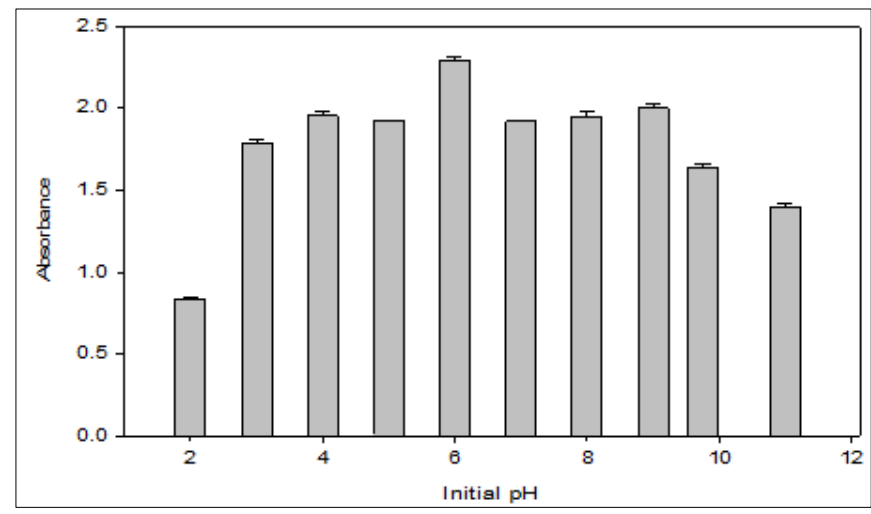

Figure 7. Effect of $\mathrm{pH}$ on the reaction of ninhydrin with lysine $1 \mathrm{mmol} \mathrm{L}{ }^{-1}$ for $\mathrm{t}=50 \mathrm{~min}$ and at $T=85{ }^{\circ} \mathrm{C}$ and Lys/Nin ratio $=1.67$

The $p \mathrm{H}$ of post-reaction mixture (final $p \mathrm{H}$ ) reveals further understanding of the reactional mechanism between lysine and ninhydrin. It was observed (Figure 8a) that the final $p \mathrm{H}$ was around 4 for different concentrations of lysine aqueous solutions (initial $p \mathrm{H} 9.7$ ). Consequently, the $p \mathrm{H}$ of postreaction mixture is independent of the concentration of lysine. Figure $8 b$ shows the relationship between initial and final $p \mathrm{H}$ values with Lysine $1 \mathrm{mmol} \mathrm{L}^{-1}$. In fact, it has not been seen any color of samples at initial $p \mathrm{H}$ lower than 2, which can be explained by the absence of the decarboxylation of lysine caused by the existence of the form $\mathrm{Lys}^{2+}$ in solution. When the initial $p \mathrm{H}$ of lysine solutions are below 4, the final $p \mathrm{H}$ exhibited an upward trend towards the values around 4. For initial $\mathrm{pH}$ above 4, the final $p \mathrm{H}$ had a downward trend stabilizing at approximately 4 . This can be explained by the amphoteric character of lysine. In addition, the decrease in $p \mathrm{H}$ to about 4 for initial $p \mathrm{H}$ higher than 4 , can probably be explained by the formation of a weak acid, namely by the carbonation of the solution, occurred due to lysine decarboxylation during the heating process, as stressed by Bordons (1986) [18]. However, there was no impact on the ninhydrin reagent since dissolved carbon dioxide helps to provide more $\mathrm{H}^{+}$which improves the reaction rate. For initial $p \mathrm{H}$ values lower than 4 , there were sufficiently protons $\mathrm{H}^{+}$thus the increasing of $\mathrm{H}^{+}$concentration shifted the equilibrium towards the direction to reduce the protons $\mathrm{H}^{+}$, this can be achieved by controlling in the production of $\mathrm{CO}_{2}$. It can be concluded that $\mathrm{CO}_{2}$ acts as a $p \mathrm{H}$ regulator in the reaction mixture which is justified by the shape of the curve of Figure 8b.
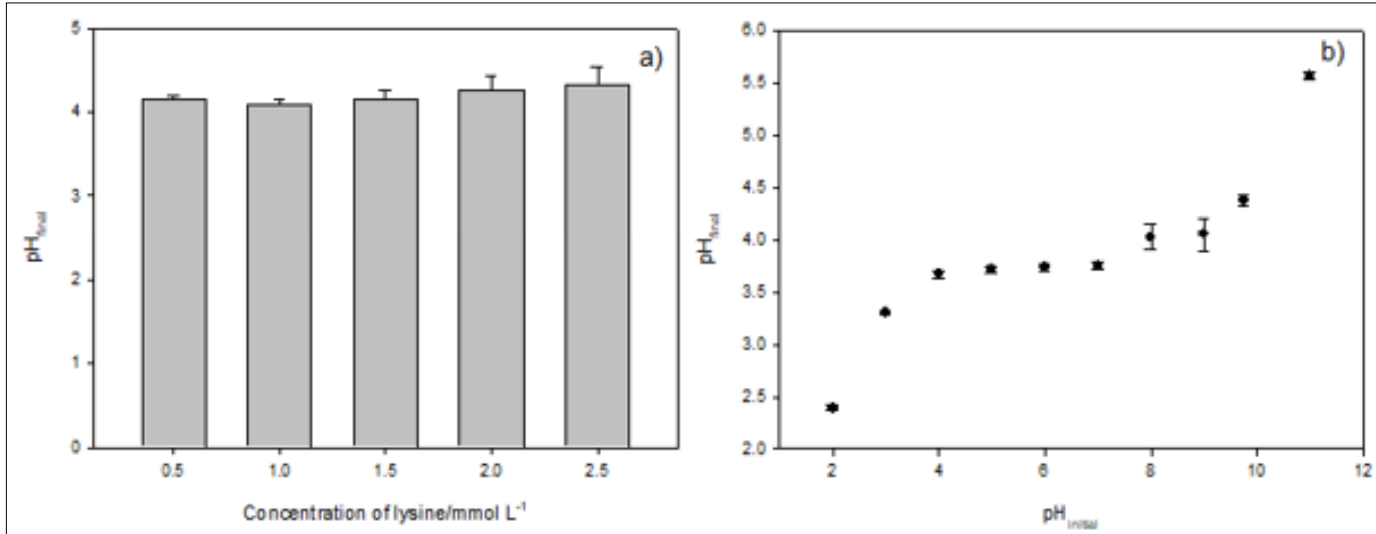

Figure 8. a) Effect of lysine concentration at natural $p \mathrm{H}$ (initial $p \mathrm{H} 9.7$ for all lysine concentrations) on the final $p \mathrm{H}$ and $\mathrm{b}$ ) relationship between initial and final $p \mathrm{H}$ values for $1 \mathrm{mmol} \mathrm{L}^{-1}$ lysine solutions

\section{Optimization of lysine analysis using an experimental design}

In order to find optimal conditions for lysine analysis, 18 experiments based on a full-factorial design with 4 factors at two levels (Table 1), including two replicates at central point, were performed. The lysine concentration was set at $1 \mathrm{mmol} \mathrm{L}^{-1}$. Table 2 shows the results of the response variable 
(absorbance) for different experimental conditions established by the full-factorial design. Considering that the main goal is to maximize the absorbance, it is noticeable from Table 2 that the region of the optimum response is obtained for high contact time and temperature, and intermediate values for the lysine/ninhydrin. These results are consistent with ones obtained previously where the effect of each variable was evaluated in separate.

Table 1. Experimental range and levels of the factors for lysine analysis

\begin{tabular}{cccc}
\hline Factor & Low level (-1) & Central point $(\mathbf{0})$ & High level $(+\mathbf{1})$ \\
\hline Time $(\min )$ & 20 & 40 & 60 \\
Lys/Nin ratio & 1 & 3 & 5 \\
pH & 2 & 6 & 10 \\
Temperature $\left({ }^{\circ} \mathrm{C}\right)$ & 75 & 80 & 85 \\
\hline
\end{tabular}

Table 2.Results from experimental design for the lysine analysis

\begin{tabular}{cccccc}
\hline Run & Time $(\mathbf{m i n})$ & Lys/Nin ratio & $\mathbf{p H}$ & $\mathbf{T}\left(\mathbf{}^{\mathbf{0}} \mathbf{C}\right)$ & Abs \\
\hline 1 & 20 & 1 & 2 & 75 & 0.280 \\
2 & 60 & 1 & 2 & 75 & 0.778 \\
3 & 20 & 5 & 2 & 75 & 0.159 \\
4 & 60 & 5 & 2 & 75 & 0.411 \\
5 & 20 & 1 & 10 & 75 & 0.312 \\
6 & 60 & 1 & 10 & 75 & 1.109 \\
7 & 20 & 5 & 10 & 75 & 0.415 \\
8 & 60 & 5 & 10 & 75 & 0.477 \\
9 & 20 & 1 & 2 & 85 & 0.734 \\
10 & 60 & 1 & 2 & 85 & 1.213 \\
11 & 20 & 5 & 2 & 85 & 0.369 \\
12 & 60 & 5 & 10 & 85 & 1.383 \\
13 & 20 & 1 & 10 & 85 & 0.574 \\
14 & 60 & 1 & 10 & 85 & 1.315 \\
15 & 20 & 5 & 10 & 85 & 0.257 \\
16 & 60 & 5 & 6 & 80 & 0.462 \\
17 & 40 & 3 & 6 & 80 & 0.902 \\
18 & 40 & 3 & & & 0.964 \\
\hline
\end{tabular}

The Pareto chart showed in Figure 9 allows evaluating the importance of each factor as well as their interactions on the response variable for a 95\% confidence interval ( $\mathrm{p} \leq 0.05)$. It can be concluded that the variable most relevant for achieving the highest values for the absorbance is the time. However, the Lys/Nin ratio and temperature may be also considered statistically significant whereas the solution $p \mathrm{H}$ has little effect on the response variable. 


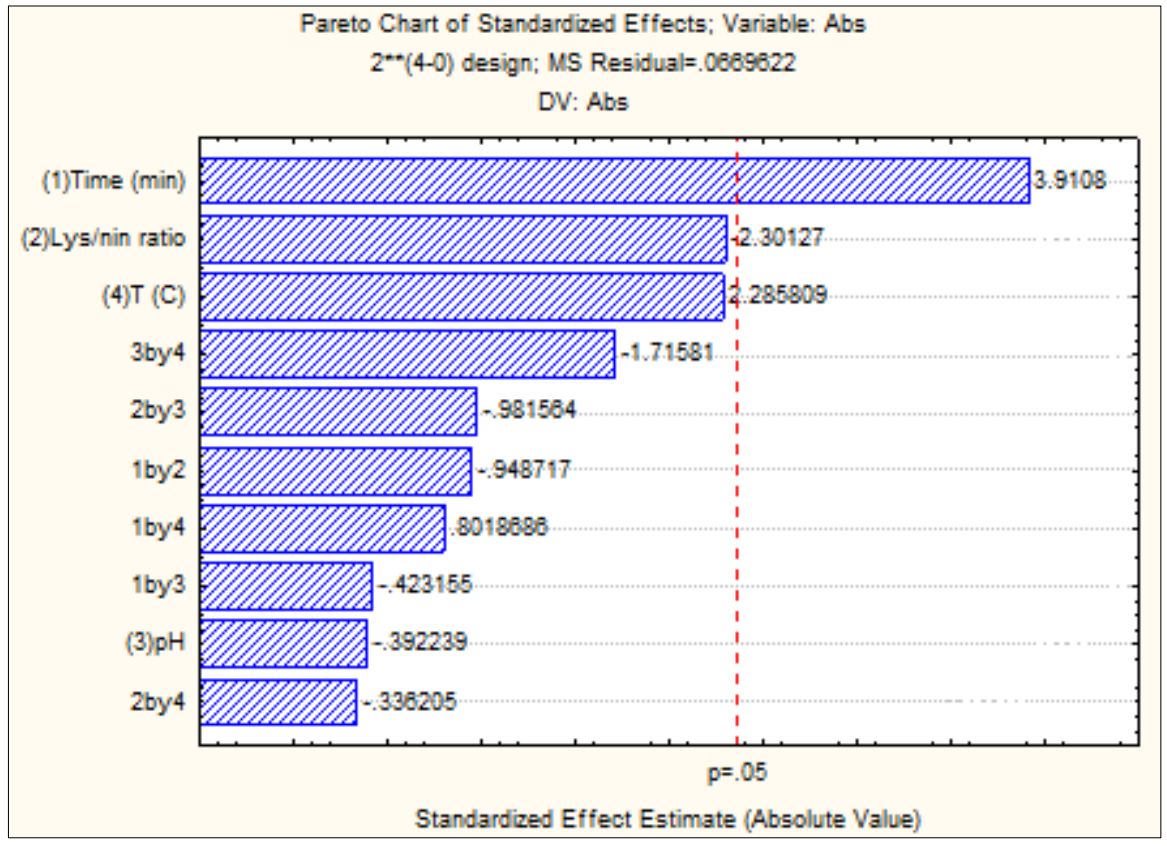

Figure 9. Pareto chart obtained from experimental design

The optimal values of the studied parameters enabled to perform the calibration curves of the absorbance vs lysine concentration (Figure 10a) and Lysine-KCl solution concentration (Figure 10b) under optimal conditions. Thus, it will be possible to analyze lysine solutions in a frequent way with ease, swiftness, and accuracy while avoiding polluting the environment.

It is worth mentioning that the calibration curves illustrated in Figures 10a and 10b were performed with lysine solutions at natural $p \mathrm{H}$ since it has little effect on the response variation compared to other optimized parameters. Further studies involving the adsorption of Lysine by a cationic resin will be carried out under these conditions.

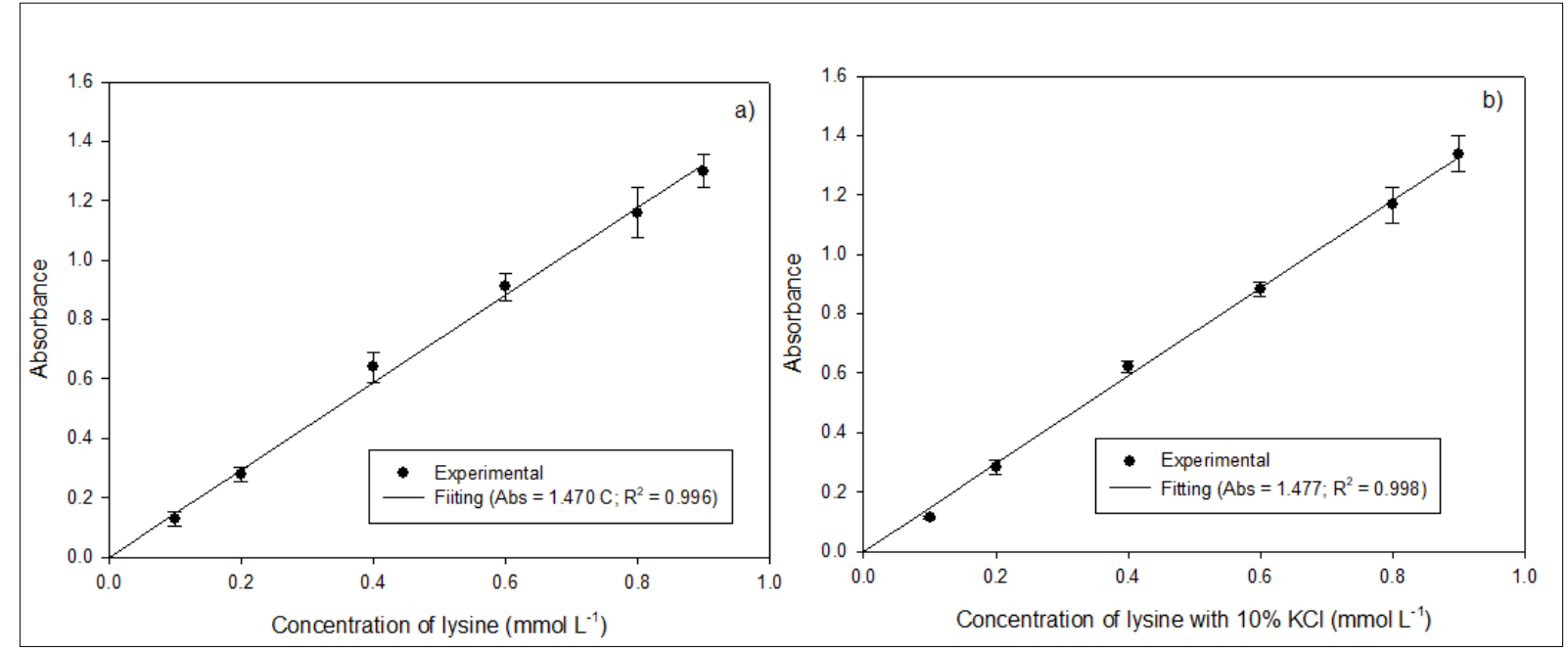

Figure 10. Calibration curves for a) lysine and b) Lysine- $\mathrm{KCl}$ solution under optimal conditions (at $85^{\circ} \mathrm{C}$, natural $p \mathrm{H}(9.7), \mathrm{t}=50 \mathrm{~min}$ and Lys/Nin ratio $=1.67$ )

\section{Method validation}

\section{Calibration curves and linearity}

As shown, the determination coefficients $\left(R^{2}\right)$ obtained from the linear regression analysis of data corresponding to absorbance vs lysine concentration, Figure 10a, and absorbance vs Lysine-KCl solution concentration, Figure 10b, are higher than 0.99 (0.996 and 0.998 respectively), which goodness of the fitting [36,47]. 


\section{Precision}

The $R S D$, as repeatability (for the $1^{\text {st }}$ day), values computed from the calibration curve, Absorbance vs Lysine concentration, ranged from 4.4 to $19.6 \%$ in which the amino acid concentration was changed from $0.1 \mathrm{mmol} \mathrm{L}^{-1}$ to $0.9 \mathrm{mmol} \mathrm{L}^{-1}$ (Table 3). These values meet the USEPA (United States Environmental Protection Agency) [48] quality control criteria. In the case of the calibration using Lysine-KCl solution, the RSD values, for the same day, varied between 2.78 and $9.07 \%$ for concentrations in the range from 0.1-0.9 $\mathrm{mmol} \mathrm{L}^{-1}$. These values meet the IUPAC (International Union of Pure and Applied Chemistry) [49] and USEPA [48] quality control criteria, $R S D \%$ lower than $20 \%$ shows the high-level precision of the method [32,33, 49,50,51]. For the $2^{\text {nd }}$ day, the $R S D$, as intermediate precision, ranged from 4.6 to $17.8 \%$ for lysine varying from $0.1 \mathrm{mmol} \mathrm{L}^{-1}$ to $0.9 \mathrm{mmol} \mathrm{L}^{-}$ 1 . These values are within the USEPA quality control criteria. For Lysine- $\mathrm{KCl}$ solution, the $R S D\left(2^{\text {nd }}\right.$ day) varied from 4.0 to $14.4 \%$ for the same concentration range. These values are in compliance with the USEPA quality control criteria [48].

Table 3. Method precision of the proposed method

\begin{tabular}{ccccc}
\hline $\begin{array}{c}\text { Concentration } \\
\left(\mathbf{m m o l ~ L}^{-1}\right)\end{array}$ & \multicolumn{2}{c}{ Repeatability (RSD\%) } & \multicolumn{2}{c}{ Intermediate precision (RSD\%) } \\
\cline { 2 - 5 } & Lysine & Lysine-KCl & Lysine & Lysine-KCl \\
\hline 0.1 & 19.6 & 04.34 & 17.82 & 06.7 \\
0.2 & 08.53 & 09.08 & 08.48 & 14.42 \\
0.4 & 07.86 & 03.25 & 08.14 & 06.73 \\
0.6 & 05.04 & 02.79 & 04.57 & 07.15 \\
0.8 & 07.27 & 05.11 & 10.02 & 05.23 \\
0.9 & 04.41 & 04.53 & 06.72 & 04.01 \\
\hline
\end{tabular}

\section{Limits of detection (LOD) and limits of quantification (LOQ)}

The $L O D$ and $L O Q$ values found from data of absorbance vs lys concentration are, respectively, $0.056 \mathrm{mmol} \mathrm{L}^{-1}\left(0.008 \mathrm{mg} \mathrm{mL}^{-1}\right)$ and $0.169 \mathrm{mmol} \mathrm{L}^{-1}\left(0.025 \mathrm{mg} \mathrm{mL}^{-1}\right)$. For the calibration data with Lysine- $\mathrm{KCl}$ solution, $L O D$ and $L O Q$ of $0.011 \mathrm{mmol} \mathrm{L}^{-1}\left(0.0016 \mathrm{mg} \mathrm{mL}^{-1}\right)$ and $0.033 \mathrm{mmol} \mathrm{L}^{-1}(0.0049$ mg. $\mathrm{mL}^{-1}$ ), respectively, were calculated. The $L O D$ of $0.0016 \mathrm{mg} \mathrm{mL}^{-1}$ is almost 4 times lower than that previously reported $\left(0.006 \mathrm{mg} \mathrm{mL}^{-1}\right)$ [52]. This suggests the high measurement sensitivity of the proposed method.

\section{Accuracy}

The average recovery value obtained is of $98.53( \pm 0.08) \%(\mathrm{n}=5)$ for lysine $0.1,0.2,0.4,06,0.8$ and $0.9 \mathrm{mmol} \mathrm{L}^{-1}$, which is within the ICH, USEPA and Commission Decision 2002/657/EC [53] quality control criteria [30-32,48,54,55], where the limits for recovery values are in the range of 80 and $120 \%$ (Table 4). For Lysine- $\mathrm{KCl}$, the average recovery value is of $102.95( \pm 0.2) \%(n=5)$ for the same above mentioned concentrations of lysine. This result show that the method exhibits high accuracy.

Table 4. Method recovery of the proposed method

\begin{tabular}{ccc}
\hline $\left.\begin{array}{c}\text { Concentration } \\
(\mathbf{m m o l ~ L}\end{array} \mathbf{- 1}^{\mathbf{1}}\right)$ & \multicolumn{2}{c}{ Recovery $(\%)$} \\
\cline { 2 - 3 } 0.1 & Lysine & Lysine-KCl \\
0.2 & 85.58 & 76.83 \\
0.4 & 96.67 & 96.12 \\
0.6 & 109.18 & 105.35 \\
0.8 & 102.65 & 99.64 \\
0.9 & 99.05 & 139.14 \\
\hline
\end{tabular}

\section{HPLC-DAD method for quantification of Lysine}

Figure 11 shows a representative chromatogram of L-lysine in ultrapure water, at $195 \mathrm{~nm}$. It can be observed that the peak of the analyzed compound is well defined and with a time below 6 min. 


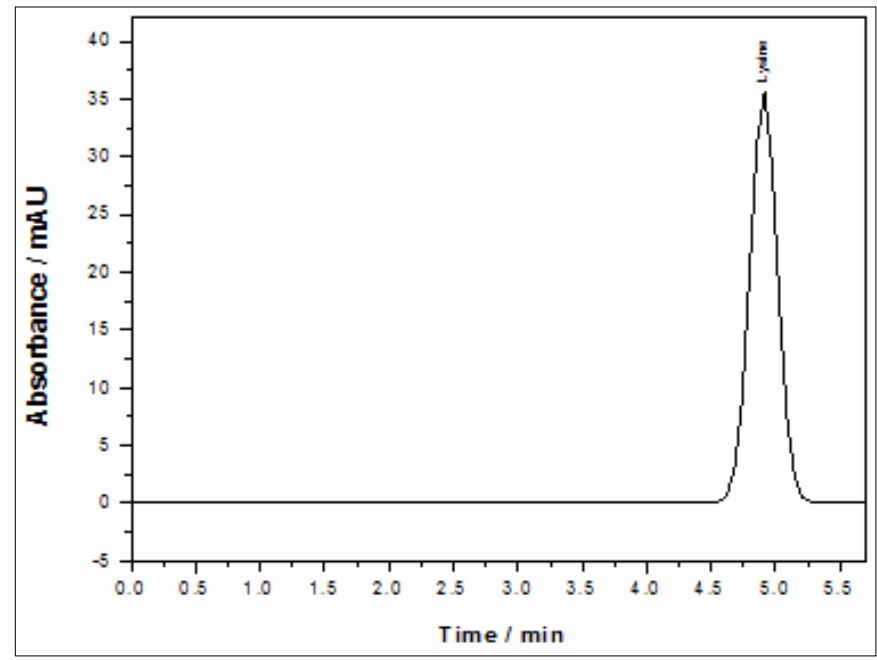

Figure 11. Chromatogram of lysine at $3 \mathrm{mmol} \mathrm{L}^{-1}$ in water, detected at $195 \mathrm{~nm}$

Figure 12 shows a calibration curve plotting the peak areas of lysine versus its corresponding concentration $\left(\mathrm{mmol} \mathrm{L}^{-1}\right)$.

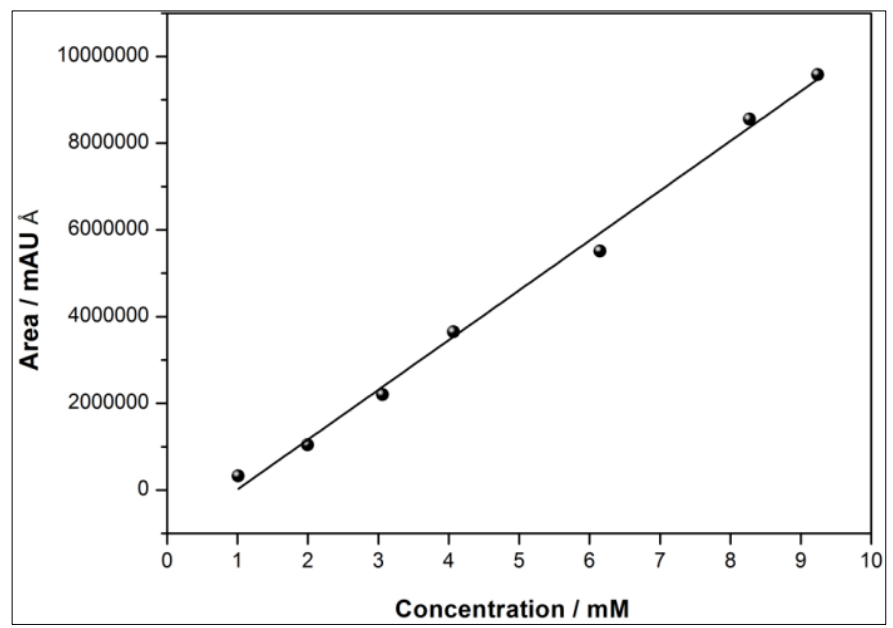

Figure 12. Calibration curve of lysine under HPLC optimized conditions

A linear correlation was found between the peak areas and the concentration of Lysine in the investigated concentration range. Table 5 summarizes the regression analysis data and the computed values for $L O D$ and $L O Q$. The linearity of the method can be confirmed since a $\mathrm{R}^{2}$ higher than 0.99 was obtained.

Table 5. Analytical and fitting parameters for the developed method for 1-lysine

\begin{tabular}{cccccccc}
\hline Compound & $\begin{array}{c}\text { Elution time } \\
(\mathbf{m i n})\end{array}$ & $\begin{array}{c}\text { Linearity range } \\
\left(\mathbf{m m o l ~ L} \mathbf{- 1}^{-1}\right.\end{array}$ & $\mathbf{n}$ & Regression equation & $\mathbf{R}^{\mathbf{2}}$ & $\begin{array}{c}\mathbf{L O D}^{*} \\
(\mathbf{m m o l} \\
\left.\mathbf{L}^{-\mathbf{1}}\right)\end{array}$ & $\begin{array}{c}\mathbf{L O Q}^{*} \\
\left(\mathbf{m m o l} \mathbf{L}^{-}\right. \\
\mathbf{1}\end{array}$ \\
\hline Lysine & 4.89 & $1-9$ & 7 & $\mathrm{y}=1.15 \mathrm{E} 6 \mathrm{x}-1.13 \times 10^{6}$ & 0.9944 & 0.57 & 1.72 \\
\hline
\end{tabular}

*limits of detection (LOD) and of quantification (LOQ)

\section{Lysine quantification in KCl aqueous solutions under HPLC optimized conditions}

Potassium chloride was used in order to test the influence of different environment in the quantification of lysine. The accuracy of the method was evaluated by determining the recovery values for three replicates using HPLC optimized conditions. Mixed solutions containing potassium chloride solution and L-lysine, at five concentration levels (1 to $8.6 \mathrm{mmol} \mathrm{L}^{-1}$ ), were prepared. The recovery 
values experimentally obtained (Table 6) range from $81.6( \pm 0.2)$ to $114.4( \pm 0.2) \%$, which are within the ICH and USEPA quality control criteria (recovery limit between 80 and $120 \%$ ) [30,48].

Table 6. Method recovery in potassium chloride matrices

\begin{tabular}{ccc}
\hline $\begin{array}{c}\text { Theoretical value of lysine } \\
\left(\mathbf{m m o l ~ L}^{-\mathbf{1}}\right)\end{array}$ & $\begin{array}{c}\text { Experimental value of lysine } \\
\left(\mathbf{m m o l ~ L}^{-\mathbf{1}}\right)\end{array}$ & Recovery $^{\mathbf{a}}(\boldsymbol{\%}) \mathbf{R S D}$ \\
\hline 1.02 & $1.25( \pm 0.04)$ & $81.6 \pm 0.2$ \\
2.3 & $2.01(0.06)$ & $114.4 \pm 0.2$ \\
4.6 & $4.25( \pm 0.13)$ & $108.2 \pm 0.3$ \\
6.29 & $5.93( \pm 0.18)$ & $106.1 \pm 0.3$ \\
8.6 & $8.62(0.26)$ & $99.77 \pm 0.01$ \\
\hline
\end{tabular}

${ }^{a}$ Mean computed from the calculated concentration in $\mathrm{mmol} \mathrm{L}^{-1}(\mathrm{n}=3)$

As aforementioned, the $L O D$ and $L O Q$ values for the ninhydrin spectrophotometric method are: $0.056 \mathrm{mmol} \mathrm{L}^{-1}$ and $0.169 \mathrm{mmol} \mathrm{L}^{-1}$, respectively. Using HPLC analysis, a $L O D$ of $0.57 \mathrm{mmol} \mathrm{L}^{-1}$ and $L O Q$ of $1.72 \mathrm{mmol} \mathrm{L}^{-1}$ were determined. Thus, it can be concluded that the spectrophotometric procedure for lysine analyses is more sensitive than HPLC technique. In addition, it should be noted the former method is more accurate, for Lys and Lys-KCl respectively, (Recovery $(\%)=98.53( \pm 0.08)$ $\%$ and $102.95( \pm 0.2) \%)$ than the HPLC method (Recovery $(\%)=81.6( \pm 0.2)-114.4( \pm 0.2)$ ).

\section{Conclusions}

This study reports an optimized methodology, by improving the reaction rate, for quantification of an amino acid lysine with ninhydrin reagent, by using UV-Visible spectrophotometry. Such development leads to a more efficient, less time-consuming and less expensive methodology when compared with those already existing. Besides, the proposed methodology has further advantages, such as a reduced reaction time $(50 \mathrm{~min})$ and reagent consumption, an accurate ratio of Lysine solution volume to ninhydrin reagent solution volume (1.67) and reduced reaction temperature $\left(85^{\circ} \mathrm{C}\right)$.

The initial $p \mathrm{H}$ effect on the reaction between lysine and ninhydrin was also investigated. Although the reaction was somewhat efficient at $p \mathrm{H} 6$, it has been found that $p \mathrm{H}$ has little effect on the response variation compared to other optimized parameters. Therefore, the natural $(p \mathrm{H} 9.7)$ lysine solution was used to further reduce the determination procedure time for lysine amino acid.

The linearity, precision, limit of detection, limit of quantification and accuracy showed the usefulness of the proposed method. The validation of the proposed method was done by comparing with the HPLC technique which highlights the merit of the present development method. In addition, it was found that potassium, as a representative interfering species, did not interfere with ninhydrin in various reaction conditions.

It can be concluded that the application of this method is not harmful towards the environment. Such results can help to maintain the best conditions for an accurate analysis of Lysine solutions by UV-Visible spectrophotometric technique.

Acknowledgements: The authors acknowledge the support of Al-IdrisiII Erasmus Mundus (European) program for HB post-doc grant. CF and AV acknowledge FCT - Fundação para a Ciência e a Tecnologia for the financial support through the project UID/QUI/00313/2019.

\section{References}

1. HERMANN, T., Industrial production of amino acids by coryneform bacteria, J Biotechnol, 104(13), 2003, 155-172.

2. NAGAI, H., CARTA, G., Lysine adsorption on cation exchange resin. I. Ion exchange equilibrium and kinetics, Sep Sci Technol, 39(16), 2004, 3691-3710. 
3. ZHANG, Y., CHEN, Y., YUE, M., JI, W., Recovery of L-lysine from L-lysine monohydrochloride by ion substitution using ion-exchange membrane, Desalination, 271(1-3), 2011, 163-168.

4.LIU, G., REN, W., FANG, J., HU, C.A.A., GUAN, G., Al-DHABI, N.A., YIN, J., DURAIPANDIYAN, V., CHEN, S., PENG, Y., YIN, Y., Amino Acids, 49(12), 2017, 1945-1954.

5.KOROSH, T.C., MARKLEY, A.L., CLARK, R.L., MCGINLEY, L.L., MCMAHON, K.D., PFLEGER, B.F., Engineering photosynthetic production of L-lysine, Metab. Eng., 44, 2017, 273-283.

6. ARDELEANU, V., BERBECE, S.I., FLORESCU, I.P., JECAN, R.C., The Use of Hyaluronic Acid Combined with Teosyal Redensity II for the Treatment of Dark Circles Under the Eyes, Mat. Plast., 54, no. 1, 2017, 37-40.

7. ZHOU, N., SHAO, Z., HUANG, Y., ZHU, T., LI,G., Electroanalysis of D-Amino Acid Oxidase and its Interaction with Hydrogen Peroxide, Anal Lett, 41(8), 2008, 1408-1418.

8. ENACHE, T.A., OLIVEIRA-BRETT, A.M., Boron doped diamond and glassy carbon electrodes comparative study of the oxidation behaviour of cysteine and methionine, Bioelectrochemistry, 81(1), 2011, 46-52.

9. BUNEA, M.C., VASILE, E., GALATEANU, B., HUDITA, A., SERBAN, M., ZAHARIA, C., Silk Fibroin Films Decorated with Magnetic Nanoparticles for Wound Healing Applications, Mater. Plast., 54, no. 1, 2017, 83-87.

10. IKEDA, M., Amino Acid Production Processes, in: Advances in biochemical engineering/ biotechnology, Scheper T., Faurie R., Thommel J. (eds.),Springer-Verlag, Berlin Heidelberg New York, 2003, vol. 79, 1-35.

11. ECKER, J., RAAB, T., HARASEK, M., Nanofiltration as key technology for the separation of LA and AA, J Membr Sci, 389, 2012, 389-398.

12. LECA-BOUVIER, B., BLUM, L.J., Biosensors for Protein Detection: A Review, Anal Lett, 38(10), 2005, 1491-1517.

13. SUN, S.W., LIN, Y.C., WENG, Y.M., CHEN, M.J., Efficiency Improvements on Ninhydrin Method for Amino Acid Quantification, J Food Compos Anal, 19(2-3), 2006, 112-117.

14.ARRUDA, P., KEMPER, E.L., PAPES, F., LEITE, A., Trends Plant Sci, 5(8), Regulation of lysine catabolism in higher plants, 2000, 324-330.

15.GUNJI, Y., YASUEDA, H., Enhancement of L-lysine production in methylotroph Methylophilus methylotrophus by introducing a mutant LysE exporter, J Biotechnol, 127(1), 2006, $1-13$.

16.CHEN, L., CHEN, Q., ZHANG, Z., Wan, X., A novel colorimetric determination of free amino acids content in tea infusions with 2,4-dinitrofluorobenzene, J Food Compos Anal, 22(2), 2009, 137 141.

17. BARBA, F.J., CARBONELL-CAPELLA, J.M., ESTEVE, M.J., FRIGOLA, A., Automating a 96Well Microtiter Plate Assay for Quick Analysis of Chemically Available Lysine in Foods, Food Anal Methods, 6(5), 2013, 1258-1264.

18.BORDONS, A., Automated determination of Lysine by colorimetric method with ninhydrin, Biotechnol Lett, 8(6), 1986, 411-414.

19.HSIEH, C.L., HSIUNG, K.P., SU, J.C., Determination of Lysine with Ninhydrin-ferric reagent, Anal Biochem, 224(1), 1995, 187-189.

20. FRIEDMAN, M., Applications of the Ninhydrin reaction for analysis of amino acids, peptides, and proteins to agricultural and biomedical sciences, J Agric Food Chem, 52(3), 2004, 385-406.

21.NAGAI, H., CARTA, G., Lysine adsorption on cation exchange resin. II. Column adsorption/ desorption behaviour and Modeling, Sep Sci Technol, 39(16), 2004, 3711-3738.

22. AIKO, R., ISHIWATA, A., MAEDA, S., Determination of free Lysine in Lysine-enriched food with acidic Ninhydrin-copper reagent, J Jpn Soc Nutr Food Sci. 24,1971, 331.

23.KABIR-UD, D., SALEM, J.K.J., KUMAR, S., KHAN, Z., Micellar and salt effects on the Ruhemann's purple formation between L-Lysine and Ninhydrin, Indian J Chem, Sect A: Inorg, Bioinorg, Phys, Theor Anal Chem, 39A(10), 2000, 1019-1023. 
24.HURST, P.L., SINCLAIR, K.B., EASON, J.R.,Amino acids interfere with the ninhydrin assay for asparagines, Food Chem, 53(4), 1995, 467-469.

25.HWANG, M.N., EDERER, G.M., Rapid hippurate hydrolysis method for presumptive identification of group B streptococci, J Clin Microbiol, 1(1), 1975, 114-115.

26.WANG, N.S., Amino acid assay by Ninhydrin colorimetric method. Available at:

http://www.engr.umd.edu/ nsw/ench485/lab3a.htm, cited on 17 Oct 2012.

27.LEHNINGER, A.L., NELSON, D.L., COX, M.M., Amino Acids and Peptides, in: Principles of Biochemistry, 2nd ed. Worth Publishers, New York, 1993, 111-133.

28.HAYAT, A., JAHANGIR, T.M., KHUHAWAR, M.Y., ALAMGIR, M., SIDDIQUI, A.J., MUSHARRAF, S.G.,Simultaneous HPLC determination of gamma amino butyric acid (GABA) and lysine in selected Pakistani rice varieties by pre-column derivatization with 2-Hydroxynaphthaldehyde, J Cereal Sci, 60(2), 2014, 356-360.

29.QADIR, M.A., AHMED, M., HUSSAIN, W.A., TAHIR, M.S., Development and Validation of New HPLC Method for Simultaneous Estimation of L-Lysine Hydrochloride and L-Carnitine LTartrate in Pharmaceutical Dosage Form, Indian Journal of Pharmaceutical Sciences, 77(4), 2015, 434438.

30. *** ICH-International Conference on Harmonisation of Technical Requirements for Registration of Pharmaceuticals for Human Use. Validation of Analytical Procedures: Text and Methodology. 1995. Q2(R1) (CPNP/ICH/381/95).

31.ALSALKA, Y., KARBEET, F., HASHEM, S., Development and Optimisation of Quantitative Analytical Method to Determine BTEX in Environmental Water Samples Using HPLC-DAD, Anal Methods, 2(8), 2010, 1026-1035.

32.FILHO, Cesar M.C., NETO, Manoel N.L., TEIXEIRA, Raquel S., PAIS, Alberto A.C.C., VALENTE, Artur J.M., Development and optimization of an HPLC-DAD method for quantification of six petroleum hydrocarbon compounds in aqueous samples, J. Liq. Chromatogr. Relat. Technol., 39(19-20), 2016, 837-846.

33. Bioanalysis, The Bioanalysis Glossary, future science group (fsg), 6(16) Suppl. 1, 2014, S1-S102. 34.***FDA-Food and Drug Administration, Office of Regulatory Affairs, ORA Laboratory Manual. Basic Statistics and Data Presentation. Vol. III, Section 4, 2019, 1-28.

35. AWOTWE-OTOO, D., AGARABI, C., FAUSTINO, P.J., HABIB, M.J., LEE, S., KHAN, M.A., SHAH, R.B., Application of Quality by Design Elements for the Development and Optimization of an Analytical Method for Protamine Sulfate, J Pharm Biomed Anal, 62, 2012,61-67.

36. AOAC-Association of Official Analytical Chemists (AOAC International), Guidelines for Single Laboratory, Validation of Chemical Methods for Dietary Supplements and Botanicals. 2002, 1-38.

37.KUMAR, B., VERMA, V.K., GAUR, R., KUMAR, S., SHARMA, C.S., AKOLKAR, A.B., Validation of HPLC Method for Determination of Priority Polycyclic Aromatic Hydrocarbons (PAHS) in Waste Water and Sediments, Adv Appl Sci Res, 5(1), 2014, 201-209.

38. WIGFIELD, D.C., BUCHANAN, G.W., CROTEAU, S.M., On Ruhemann's Purple, Can J Chem, 58(3), 1980, 201-205.

39.CHERNOBROVKIN, M.G., ANAN'EVA, I.A.,SHAPOVALOVA, E.N., SHPIGUN, O.A., Determination of amino acid enantiomers in pharmaceuticals by reversed-phase high performance liquid chromatography, J Anal Chem, 59(1), 2004, 55-63.

40. LI, W., HOU, M., CAO, Y., SONG, H., SHI, T., GAO, X., WANG, D., Determination of 20 Free Amino Acids in Asparagus Tin by High-Performance Liquid Chromatographic Method after PreColumn Derivatization, Food Anal Methods, 5(1), 2012, 62-68.

41.WANI, Y.B., PATIL, D.D., An experimental design approach for optimization of spectrophotometric method for estimation of cefixime trihydrate using Ninhydrin as derivatizing reagent in bulk and pharmaceutical formulation, J Saudi Chem Soc, 21, 2017, S101-S111. 
42. HORN, F., LINDENMEIER, G., GRILlHOSL, C., MOC, I., BERGHOLD, S., SHNEIDER, N., MUNSTER, B., Métabolisme-Enzymes, in: Biochimie humaine, ed. Flammarion, Paris, 2005, 60-76. 43.GARRETT, R.G., GRISHAM, C.M., Enzymes-Kinetics and Specifity, in: Biochemistry, 4th ed. Brooks/Cole, Cengage Learning, Boston Toronto, 2010, 382-418.

44.WILSON, K., WALKER, J., Protein and enzyme techniques, in: Principles and techniques of practical biochemistry, $4^{\text {th }}$ ed. Cambridge Low Price, Cambridge, 1995, 162-226.

45.ROGERS, D.W., The Gibbs Free Energy, Chapter 6, in: Concise Physical Chemistry, ed. John Wiley \& Sons, Inc., Hoboken, New Jersey, USA Canada, 2011, 84-92.

46.GARRETT, R.G., GRISHAM, C.M., Amino Acids, in: Biochemistry, 4th ed. Brooks/Cole, Cengage Learning, Boston Toronto, 2010, 70-92.

47. AVRAM, N., HEGHES, S.C., RUS, L.L., JUNCAN, A.M., RUS, L.M., FILIP, L., FILIP, C.R., HPLC-UV Determination of Dextromethorphan in Syrup Method Validation, Rev. Chim., 70(2), 2019, 487-490.

48.***USEPA-United States Environmental Protection Agency, National primary drinking water standards. Available at: http://water.epa.gov/drink/contaminants, accessed in April 2016.

49.***IUPAC- International Union of Pure and Applied Chemistry, Harmonised Guidelines for the InHouse Validation of Methods of Analysis (Technical Report). IUPAC/In-House/ Budapest, 1-34.

50. PLIKAYTIS, B.D., HOLDER, P.F., PAIS, L.B., MASLANKA, S.E., GHEESLING, L.L., CARLONE, G.M., Determination of parallelism and nonparallelism in bioassay dilution curves, J Clin Microbiol., 32(10), 1994, 2441-2447.

51. AMY TAN, G.Y., CHEN, C.L., ZHAO, L., MO, Y., CHANG, W.C., WANG, J.Y., An HPLCDAD Method for Rapid and High Resolution Analysis of Concentrated BTEX and Styrene Aqueous Samples, Anal Methods, 4(11), 2012, 3545-3550.

52.CHUTIPONGTANATE,S., WATCHARATANYATIP, K., HOMVISES, T., JATURONGKAKUL, K., THONGBOONKERD, V., Systematic comparisons of various spectrophotometric and colorimetric methods to measure concentrations of protein, peptide and amino acid: Detectable limits, linear dynamic ranges, interferences, practicality and unit costs, Talanta, 98, 2012, 123-129.

53.*** European Commission, Commission Decision of 12 August 2002 Implementing Council Directive 96/23/EC Concerning the Performance of Analytical Methods and the Interpretation of Results, (2002/657/EC), L221/8-36.

54. CATANA, L., CATANA, M., IORGA, E., ASANICA, A.C., LAZAR, M.A., LAZAR, A.G., BELC, N., PIRVU, G., Internal Validation of Rapid and Performant Method for Carotenoids Determination in Tomato Waste Powder by HPLC, Rev. Chim., 71(1), 2020, 342-349.

55. ROSCA, A.C., RONCEA, F.N., IANCU, V., STOICESCU, I., CAZACINCU, R., IANCU, I., MIRESAN, H., Development and Validation of HPLC-DAD Method for Diclofenac Sodium Assay from New Orodispersible Tablets with Co-Processed Excipients, Rev. Chim., 71(2), 2020, 335-343.

Manuscript received: 20.04 .2020 


\section{SUPLEMENTARY MATERIAL}



Figure S1.Absorbance spectrums of product peak from 400 to $800 \mathrm{~nm}\left(\lambda_{\max }=479 \mathrm{~nm}\right)$ of Lysine $1 \mathrm{mmol} \mathrm{L}^{-1}$ contaminated with $10 \% \mathrm{KCl}$ and reacted with ninhydrin in the water-bath at different physicochemical conditions: (1) time: $20 \mathrm{~min}$, ratio $1, p \mathrm{H} 9.7, \mathrm{~T}=75^{\circ} \mathrm{C}$; (2) time: $20 \mathrm{~min}$, ratio $1, p \mathrm{H} 2, T=75^{\circ} \mathrm{C}$; (3) time: $20 \mathrm{~min}$, ratio $3, p \mathrm{H} 6, T=80^{\circ} \mathrm{C}$; (4) time: $40 \mathrm{~min}$, ratio 3 , $p \mathrm{H} 6, T=80^{\circ} \mathrm{C}$; (5) time: $60 \mathrm{~min}$, ratio $3, p \mathrm{H} 6, T=80^{\circ} \mathrm{C}$

Table S1. Composition of lysine solutions

\begin{tabular}{cc}
\hline Lysine-KCl solutions & KCl stock solution $(\mathbf{m L})$ \\
\hline Lysine $1 \mathrm{mmol} \mathrm{L}^{-1}-\mathrm{KCl}$ & 3.8 \\
Lysine $2 \mathrm{mmol} \mathrm{L}^{-1}-\mathrm{KCl}$ & 7.5 \\
Lysine $4 \mathrm{mmol} \mathrm{L}^{-1}-\mathrm{KCl}$ & 14.9 \\
Lysine $6 \mathrm{mmol} \mathrm{L}^{-1}-\mathrm{KCl}$ & 22.4 \\
Lysine $8 \mathrm{mmol} \mathrm{L}^{-1}-\mathrm{KCl}$ & 29.8 \\
\hline
\end{tabular}

